\title{
Peran Bimbingan Konseling Berbasis Tiga Pilar (Guru, Orang Tua, dan Lingkungan Masyarakat) dalam Pembentukan Akhlakhul Karimah Siswa di MA Nurul Huda Kabupaten OKU Timur
}

\author{
Ayu Lusiyana ${ }^{3}$, Fatkhur Rohman ${ }^{2}$, Saifur Rohim ${ }^{3}$, \\ 1, 2 Mahasiswa Program Doktoral Ilmu Pendidikan Universitas Negeri Padang \\ 3 Guru Madrasah Aliyah Nurul Huda Sukaraja Kabupaten OKU Timur \\ Email: ayulusiyana91@gmail.com
}

\begin{abstract}
Abstrak
Keberhasilan layanan bimbingan konseling tidak hanya sepenuhnya diserahkan kepada guru pembimbing/konselor sekolah, melainkan kerjasama untuk setiap elemen pendidikan yaitu: lingkungan sekolah (guru), lingkungan keluarga (orang tua), dan lingkungan masyarakat.

Lingkungan sekolah merupakan pusat dalam layanan konseling siswa, setiap personil dalam lingkungan sekolah memiliki peranan yang sama penting, karena dalam keterlaksanaan layanan konseling di sekolah merupakan satu kesatuan kerjasama antara anggota-anggotanya. Personil lingkungan sekolah dalam layanan bimbingan konseling terdiri dari kepala sekolah, wakil kepala sekolah, pengawas guru BK, guru BK, wali kelas, guru mata pelajaran, staf administrasi sekolah, dan siswa sebagai objek layanan.
\end{abstract}

Kata kunci : Bimbingan Konseling (Guru, Orang Tua, Lingkungan Masyarakat), Pembentukan Ahlakul Karimah

\section{PENDAHULUAN}

Peningkatan kualitas diri dalam bentuk kepribadian yang bersahaja dan baik merupakan usaha yang dilakukan dalam proses pendidikan. Begitu pentingnya peran pendidikan dalam kehidupan manusia, sehingga pendidikan menjadi sebuah tujuan dan prioritas utama sebuah bangsa. Hal ini sesuai dengan Undang-undang Nomor 20 Tahun 2003 tentang Sistem Pendidikan Nasional menyatakan bahwa Pendidikan Nasional bertujuan untuk mencerdaskan kehidupan bangsa dan mengembangkan manusia seutuhnya. Makna manusia seutuhnya adalah manusia yang berakhlakul karimah tercermin dalam kepribadian budi yang luhur dan memiliki karakter baik dalam menjalankan hidup serta kehidupan dilingkungan masyarakat. Dat Simanullang, Wahjoedi dan Sapto (2017) menyebutkan bahwa pendidikan merupakan usaha sadar dan terencana untuk mengembangkan kepribadian dan kemampuan di dalam dan diluar sekolah seumur hidup. Oleh karena itu pendidikan tidak hanya menjadi tanggung jawab guru saja di lingkungan sekolah, tetapi juga menjadi tanggung jawab semua pihak baik orang tua, keluarga, dan lingkungan masyarakat.
Sebagai seseorang individu yang berada dalam proses perkembangan pemikirannya menuju kematangan/pendewasaan dalam bertindak, siswa memerlukan konseling dari guru, orang tua dan lingkungan masyarakat dalam proses pembelajarannya untuk membentuk aklakul karimah dalam diri siswa. Tiga pilar konseling pendidikan tersebut memiliki peran yang sama-sama penting, hal ini dijelaskan Gunarsa (2009); Simanullang, Wahjoedi dan Sapto (2017) bahwa pola didik orang tua dalam keluarga merupakan merupakan basis pendidikan yang pertama dan utama dalam pembentukan karakter siswa. Sejalan dengan hal tersebut Mizan (2012); Hasgimianti, Nirwana dan Daharnis (2017) menjelaskan bahwa orang tua memiliki bagian penting untuk membantu anak mencapai hasil belajar yang lebih baik dengan memberikan kasih sayang dan pendidikan melalui nilai-nilai kehidupan, baik nilai agama maupun nilai budaya sosial. Salah satu bentuk peran orang tua memberi perhatian pada anak mereka dalam membentuk karakter akhlakuk karimah dalam diri anak. Lingkungan keluarga yang mampu menerapkan kedisiplinan pada anak turut berdampak pada kedisiplinan siswa di sekolah Monalisa (2016). Selain itu perkembangan siswa juga tidak lepas dari 
pengaruh lingkungan, baik fisik, psikis maupun akhlakul karimah siswa di Madrasah Aliyah sosial. Sifat yang melekat pada lingkungan Nurul Huda Sukaraja Kabupaten OKU Timur. adalah perubahan. Perubahan yang terjadi dalam lingkungan dapat mempengaruhi gaya hidup (life style) yang mengarah pada pembentukan kepribadian siswa dalam menjalani hidup bermasyarakat Yarliani (2013). Berdasarkan ulasan tersebut, pembentukan akhlakul karimah siswa bukan hanya terjadi di lingkungan madrasah saja, lingkungan masyarakat terutama keluarga juga berperan penuh dalam pembentukan dasar akhlakul karimah siswa.

\section{METODOLOGI}

Jenis pendekatan yang digunakan dalam penelitian ini adalah pendekatan kualitatif studi kasus dengan metode desktiptif masalah, dimana metode yang menggambarkan secara objektif tentang peranan bimbingan konseling berbasis tiga pilar (guru, orang tua dan lingkungan masyarakat) dalam Pembentukan Akhlakhul

Pembentukan akhlakul karimah di dalam Karimah Siswa di MA Nurul Huda Sukaraja diri siswa Madrasah Aliyah Nurul Huda menjadi Kabupaten OKU Timur yang didapatkan dari prioritas dasar sebelum pembentukan kecerdasan hasil dokumentasi dan angket. Data yang intelektual siswa, hal ini memiliki dasar alasan didapatkan berkaitan dengan informasi yang yang kuat bahwa Madrasah Aliyah Nurul Huda berkaitan dengan akhlakul karimah dari siswa adalah salah satu lembaga pendidikan yang Madrasah Aliyah Nurul Huda dengan indikator berada langsung di bawah naungan Yayasan capaian sikap seperti disajikan dalam Tabel 1.

Pondok Pesantren Nurul Huda dengan visi "Terciptanya Insan yang Beriman dan Taqwa (IMTAQ), Berilmu Pengetahuan Teknologi (IPTEK), dan Berakhlakul Karimah". Berdasarkan visi tersebut, menjadikan tantangan serta peluang bagi pengelola madrasah dengan melibatkan seluruh elemen pendidikan (guru, orang tua, dan lingkungan masyarakat) dalam kegiatan bimbingan dan konseling untuk membentuk pribadi siswa yang berakhlakul karimah.

Melalui kegiatan layanan layanan bimbingan dan konseling dengan melibatkan guru, orang tua, dan lingkungan masyarakat secara efektif, maka setiap siswa mendapat kesempatan untuk mengembangkan setiap kecakapan dan kemampuannya semaksimal mungkin. Dengan kata lain bisa dikatakan bahwa bimbingan dapat mempertemukan antara kemampuan individu dengan cita-citanya dan juga dengan masyarakat (Djumhur dan Moh. Surya, 2003).

Berdasarkan penjelasan di atas, peneliti tertarik untuk mengkaji secara mendalam berkaitan dangan Peran Bimbingan Konseling Berbasis Tiga Pilar (Guru, Orang Tua, dan Lingkungan Masyarakat) dalam Pembentukan Akhlakhul Karimah Siswa yang sudah dilakakukan di MA Nurul Huda Kabupaten OKU Timur. Tujuan dalam penelitian ini adalah melihat dampak dari pelaksanaan program bimbingan konseling dengan tiga pilar pendidikan yang sudah dirancang dan dilaksanakan oleh pengelola Yayasan Pondok Pesantren Nurul Huda dalam pembentukan sikap

Tabel 1. Indikator capaian pembentukan akhlakul karimah

\begin{tabular}{|l|l|}
\hline No & \multicolumn{1}{|c|}{$\begin{array}{c}\text { Indikator Pembentukan } \\
\text { Akhlakul Karimah }\end{array}$} \\
\hline 1 & $\begin{array}{l}\text { Nilai Religius (beriman dan } \\
\text { bertakwa kepada Allah) }\end{array}$ \\
\hline 2 & Nilai Jujur \\
\hline 3 & Nilai Toleransi/Menghargai \\
\hline 4 & Nilai Disiplin \\
\hline 5 & Nilai Kerja Keras \\
\hline 6 & Nilai Kreatif \\
\hline 7 & Nilai Mandiri \\
\hline 8 & Nilai Peduli Lingkungan \\
\hline
\end{tabular}

\section{Subjek dan Objek Penelitian}

Peranan tiga pilar (guru, orang tua dan lingkungan masyarakat) penting dalam pelaksanaaan bimbingan dan konseling dalam penelitian ini menjadi sibjek penelitian.

Sedangkan perubahan akhlakul karimah siswa Madrasah Aliyah Nurul Huda melalui peranan tiga pilar penting dalam pelaksanaan bimbingan konseling manjadi objek dalam penelitian ini. Jumlah objek dalam penelitian ini dapat dilihat pada Tabel 2.

Tabel 2. Jumlah siswa Madrasah Aliyah Nurul

Huda
\begin{tabular}{|l|l|l|}
\hline No & Kelas & Jumlah \\
\hline 1 & $X_{1}$ & 21 Siswa \\
\hline 2 & $X_{2}$ & 23 Siswa \\
\hline 3 & $X_{3}$ & 21 Siswa \\
\hline 4 & XI IPA & 22 Siswa \\
\hline
\end{tabular}




\begin{tabular}{|c|c|c|}
\hline 5 & XI IPS & 29 Siswa \\
\hline 6 & XI MAK & 27 Siswa \\
\hline 7 & XII IPA & 23 Siswa \\
\hline 8 & XII IPS & 21 Siswa \\
\hline 9 & XII IPS & 22 Siswa \\
\hline 10 & XII MAK & 23 Siswa \\
\hline \multicolumn{2}{|c|}{ Jumlah } & 232 Siswa \\
\hline
\end{tabular}

Sumber: Tenaga administrasi MA Nurul Huda

Berdasarkan tabel 2 jumlah populasi dalam penelitian ini adalah 232 responden. Sugiyono (2017) menyebutkan bahwa dengan taraf signifikansi 5\% maka jumlah sampel yang dapat digunakan dalam penelitian berjumlah 139 .

\section{Data dan Sumber Data Penelitian}

Data penelitian yang berkaitan dengan indikator pembentukan akhlakul karimah siswa Madrasah Aliyah Nurul Huda Sukaraja Kabupaten OKU Timur seperti yang sudah dijelaskan dalam Tabel 1 yaitu berkaitan dengan 1) Nilai Religius (beriman dan bertakwa kepada Allah); 2) Nilai Jujur; 3) Nilai Toleransi/Menghargai; 4) Nilai Disiplin; 5) Nilai Kerja Keras; 6) Nilai Kreatif; 7) Nilai Mandiri; dan 8) Nilai Peduli Lingkungan. Data tersebut didapatkan melalui pengumpulan data seperti observasi, data dokumentasi dan angket. Sedangkan sumber data yang berkaitan dengan peranan guru, orang tua dan lingkungan masyarakat dalam pelaksanaan bimbingan konseling untuk pembentukan akhlakul karimah siswa Madrasah Aliyah Nurul Huda sumber data berasal dari arsip dokumentasi guru pembimbing.

\section{Teknik Pengumpulan Data}

Teknik pengumpulan data seperti yang telah dijelaskan sebelumnya dalam penelitian ini untuk mendapatkan informasi yang akurat den relaven. Teknik pengumpulan data dalam penelitian ini dilakukan dengan:

1. Wawancara, dilakukan untuk melihat deskripsi pengelolaan layanan konseling yang dilakukan oleh guru pembimbing. Wawancara dilakukan kepada kepala sekolah dan guru pembimbing

2. Dokumentasi, teknik dokumentasi dalam penelitian ini digunakan untuk mengambil data-data dari guru pembimbing mengenai program kerja bimbingan dan konseling berkaitan dengan pelaksanaan layanan konseling berbasis tiga pilar pendidikan (guru, orang tua dan lingkungan masyarakat);

3. Angket, yang diberikan kepada siswa untuk melihat efektifitas pelayanan bimbingan konseling dalam upaya pembentukan akhlakul karimah siswa MA Nurul Huda.

\section{Teknik Analisis Data Penelitian}

Teknik analisis data yang digunakan dalam penelitian ini adalah analisis deskriptif data. Data penelitian yang telah terkumpulkan melalui

wawancara dokumentasi dan angket dapat

dideskriptifkan berupa kata-kata, persentase, dan rerata.

1. Analisis data dokumentasi dalam penelitian ini berupa penjelasan yang merujuk pada arsip-arsip administrasi dalam layanan kegiatan bimbingan konseling di MA Nurul Huda dan persentase berdasarkan arsip data guru pembimbing terkait dengan peranan responden (orang tua siswa) terhadap layanan bimbingan konseling di sekolah;

2. Analisis data angket dalam penelitian ini berupa nilai rerata dan persentase terkait dengan penilaian siswa terhadap efektifitas pelayanan bimbingan konseling dalam upaya pembentukan akhlakul karimah siswa di MA Nurul Huda.

Untuk mencari nilai rerata dan persentasi capaian efektifitas layanan konseling menggunakan persamaan 1 .

$\bar{X}=\frac{\sum_{i=1}^{N} X_{i}}{N}$ dan $\quad P=\bar{X} \times 100 \%$

Keterangan

$\bar{X} \quad=$ Nilai rerata penilaian hasil validasi

$\sum_{i=1}^{N} X_{i} \quad=$ Jumlah skor aspek penilaian penilaian

validasi

$=$ Jumlah validator

Interpretasi penilaian capaian efektifitas layanan konseling mengacu pada Tabel 3.

Tabel 3. Klasifikasi interpretasi penilaian

capaian efektifitas layanan konseling

\begin{tabular}{|l|l|}
\hline Rerata Skor & Klasifikasi \\
\hline $\bar{X}>4,2$ & Sangat efektif \\
\hline $\bar{X}>3,4-4,2$ & Efektif \\
\hline
\end{tabular}




\begin{tabular}{|l|l|}
\hline $\bar{X}>2,6-3,4$ & Cukup efektif \\
\hline $\bar{X}>1,8-2,6$ & Tidak efektif \\
\hline $\bar{X} \leq 1,8$ & $\begin{array}{l}\text { Sangat tidak } \\
\text { efektif }\end{array}$ \\
\hline
\end{tabular}

Sumber: Dimodifikasi dari Putro (2017)

\section{HASIL PENELITIAN}

Data hasil penelitian yang akan dikaji dapam penelitian ini adalah adalah data hasil penelitian studi kasus yang dikumpulkan dengan beberapa teknik pengumpulan data yaitu wawancar, teknik dokumentasi dan angket. Data tersebut akan ditampilkan dalam bentuk penjelasan dan deskripsi rerata dan persentase. Penjelasan hasil penelitian dapat disajikan sebagai berikut:

\section{Deskripsi Layanan Bimbingan dan Konseling di MA Nurul Huda}

Madrasah Aliyah Nurul Huda memiliki visi "Terciptanya Insan yang Beriman dan Taqwa (IMTAQ), Berilmu Pengetahuan Teknologi (IPTEK), dan Berakhlakul Karimah", dari visi tersebut untuk mewujudkannya tentu pihak pengelola sekolah memiliki strategi atau program dalam layanan bimbingan konseling dalam pembentukan akhlakul karimah siswa MA Hurul Huda. Berdasarkah hasil wawancara dengan kepala sekolah, guru pembimbing dalam mewujudkan visi tersebut pada pelayanan bibingan konseling terhadap siswa selalu melibatkan tiga pilar utama pendidikan yaitu: 1) guru sebagai sumber inforasi terkait dengan kemajuan akademik siswa dam perubahan akhlakul karimah saat proses pembelajaran, 2) orang tua/keluarga sebagai sumber informasi terkait dengan sikap dan tingkah laku siswa selama bergaul dengan keluarga, 3) masyarakat sebagai sumber informasi dan pengendali siswa dalam menerapkan ilmu dan bersikap terhadap pergaulan sehari-hari siswa.

Bimbingan konseling dengan melibatkan tiga pilar utama pendidikan sangat menjanjikan dalam pembentukan karakter akhlakul karimah siswa di MA Nurul Huda, karena dalam praktiknya secara ideal siswa akan selalu didampingi terus, dibimbing dan dikontrol dalam lingkungan keseharian siswa (lingkungan sekolah, lingkungan keluarga, dan lingkungan masyarakat). Namun dalam praktiknya hal ini tidaklah gampang, dari hasil wawancara guru pembimbing di MA Nurul Huda menyatakan bahwa "Program konseling ini diterapkan di MA Nurul Huda pada awal tahun pembelajaran 2013/2014, kesulitan pertama ada pada penyatuan pikiran dan pendapat dari tiga pilar pendidikan (lingkungan sekolah, lingkungan keluarga, dan lingkungan masyarakat) dalam melaksanakan layanan konseling. Namun dengan memberikan pemahaman terhadap keluarga, dan lingkungan masyarakat terkait dengan pentingnya karakter yang terbentuk melalui akhlakul karimah siswa sebagai pembentukan generasi berkualitas, serta hasilnya akan berdampak terhadap keluarga dan lingkungan masyarakat, program ini mulai berjalan ke arah yang lebih baik dan kondusif dalam layanannya". Berdasarkan hasil analisis dokumentasi administrasi guru pembimbing dalam layanan bimbingan konseling berbasis tiga pilar utama pendidikan lima tahun terakhir kepedulian orang tua/keluarga dan masyarakat akan layanan konseling di MA Nurul Huda dapat didsekripsikan dalam presentase grafik Gambar 1 dan 2.

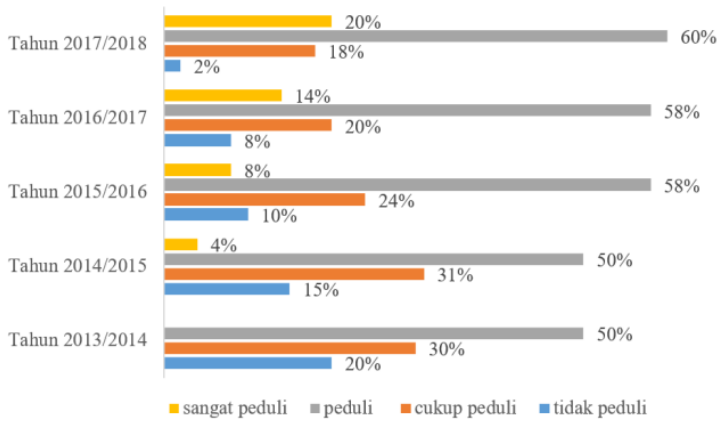

Gambar 1. Grafik kepedulian dalam peranan orang tua terhadap layanan konseling di MA Nurul Huda

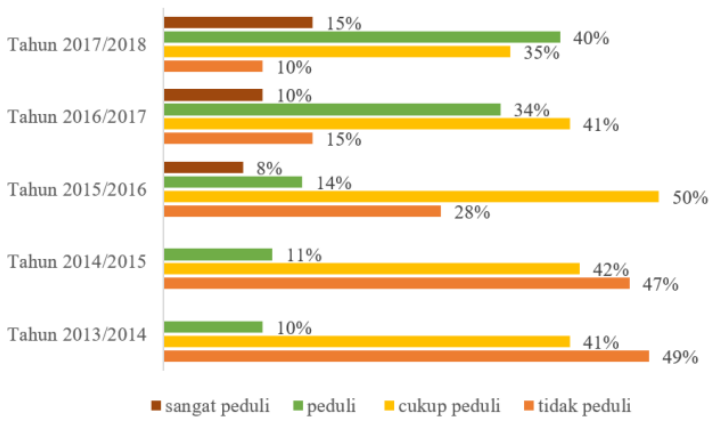

Gambar 2. Grafik kepedulian dalam peranan lingkungan masyarakat terhadap layanan konseling di MA Nurul Huda

Deskripsi Gambar 1 dan 2 memberikan gambaran bahwa pelaksanaan layanan konseling berbasis tiga pilar yang di lakukan sekolah dari tahun pembelajaran 2013/2014 samapi dengan 
2017/2018 dilihat dari persentase kepedulian terhadap layanan konseling mengalami peningkatan yang signifikan.

Data Capaian Pembentukan Akhlakhul Karimah Siswa MA Nurul Huda

Akhlakhul tidak hanya sepenuhnya diserahkan kepada guru

Data hasil capaian pembentukan akhlakul kerjasama untuk setiap elemen pendidikan yaitu: karimah siswa MA Nurul Huda didapatkan dari lingkungan sekolah (guru), lingkungan keluarga hasil wawancara kepada kepala sekolah dan guru (orang tua), dan lingkungan masyarakat.

pembimbing serta penilaian angket yang Peranan lingkungan sekolah dalam layanan diberikan kepada siswa 139 siswa sebagai bimbingan konseling

responden. Indikator capaian pembentukan Lingkungan sekolah merupakan pusat akhlakul karimah siswa mangacu pada tabel 1. Adapun hasil analisis data dapat disajikan pada tabel 3.

Tabel 3. Hasil analisis data berupa rerata dan persentase capaian akhlakul karimah siswa

\begin{tabular}{|c|c|c|c|}
\hline No & $\begin{array}{l}\text { Indikator } \\
\text { Pembentukan } \\
\text { Akhlakul } \\
\text { Karimah }\end{array}$ & Rerata & Persentase \\
\hline 1 & $\begin{array}{l}\text { Nilai Religius } \\
\text { (beriman dan } \\
\text { bertakwa } \\
\text { kepada Allah) }\end{array}$ & 4.09 & $82 \%$ \\
\hline 2 & Nilai Jujur & 4.06 & $81 \%$ \\
\hline 3 & $\begin{array}{l}\text { Nilai Toleransi } \\
\text { (Menghargai) }\end{array}$ & 3.97 & $79 \%$ \\
\hline 4 & Nilai Disiplin & 4.06 & $81 \%$ \\
\hline 5 & $\begin{array}{ll}\text { Nilai } & \text { Kerja } \\
\text { Keras } & \\
\end{array}$ & 4.09 & $82 \%$ \\
\hline 6 & Nilai Kreatif & 3.81 & $76 \%$ \\
\hline 7 & Nilai Mandiri & 3.83 & $77 \%$ \\
\hline 8 & $\begin{array}{l}\text { Nilai Peduli } \\
\text { Lingkungan }\end{array}$ & 4.14 & $83 \%$ \\
\hline \multicolumn{2}{|c|}{$\begin{array}{l}\text { Komperhensif nilai } \\
\text { Rerata dan rerata } \\
\text { persentase }\end{array}$} & 4.01 & $80 \%$ \\
\hline
\end{tabular}

Tabel 3 menunjukan bahwa nilai rerata komperhensif pada setiap penilaian adalah 4.01 dengan persentase $80 \%$. Berdasarkan tabel 3, menunjukan pada hasil kriteria penilaian $\bar{X}>3,4$ - 4,2 yang berarti bahwa layanan bimbingan konseling berbasis tiga pilar pendidikan yang dilakukan di MA Nurul Huda dalam membentuk akhlakhul karimah terlaksana efektif.

dalam layanan konseling siswa, setiap personil dalam lingkungan sekolah memiliki peranan yang sama penting, karena dalam keterlaksanaan layanan konseling di sekolah merupakan satu kesatuan kerjasama antara anggota-anggotanya. Personil lingkungan sekolah dalam layanan bimbingan konseling terdiri dari kepala sekolah, wakil kepala sekolah, pengawas guru BK, guru BK, wali kelas, guru mata pelajaran, staf administrasi sekolah, dan siswa sebagai objek layanan. Secara sederhana lingkungan sekolah dalam layanan konseling dapat dilihat pada Gambar 3.

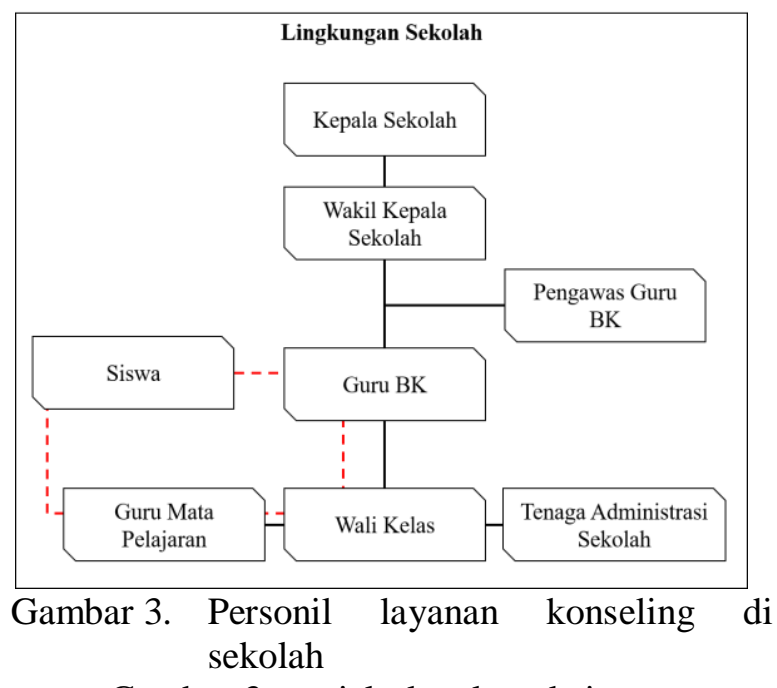

Gambar 3 menjelaskan keterkaitan peranan dari masing-masing personil pada lingkungan sekolah. Adapun masing-masing perana personil pada lingkungan sekolah adalah sebagai berikut:

1. Peranan kepala sekolah

Prayitno (2004) memerinci peran, tugas dan tanggung jawab kepala sekolah dalam bimbingan dan konseling yaitu: 1) Mengkoordinir segenap kegiatan yang diprogramkan dan berlangsung di sekolah, sehingga pelayanan pengajaran, latihan, dan bimbingan dan konseling merupakan suatu kesatuan yang terpadu, harmonis, dan 
dinamis. 2) Menyediakan prasarana, tenaga, dan berbagai kemudahan bagi terlaksananya pelayanan bimbingan dan konseling yang efektif dan efisien. 3) Melakukan pengawasan dan pembinaan terhadap perencanaan dan pelaksanaan program, penilaian dan upaya tidak lanjut pelayanan bimbingan dan konseling. 4) Mempertanggungjawabkan pelaksanaan pelayanan bimbingan dan konseling di sekolah. 5) Memfasilitasi guru pembimbing/konselor untuk dapat mengembangkan kemampuan profesionalnya, melalui berbagai kegiatan pengembangan profesi. Dan 6) Menyediakan fasilitas, kesempatan, dan dukungan dalam kegiatan kepengawasan yang dilakukan oleh Pengawas Sekolah Bidang BK.

2. Peranan wakil kepala sekolah

Wakil kepala sekolah sebagi pembantu kepala sekolah, membantu kepala sekolah dalam melaksanakan tugas-tugas kepala sekolah dalam hal: 1) Mengkoordinasikan pelaksanaan layanan bimbingan dan konseling kepada semua personil sekolah; dan 2) Melaksanakan kebijakan pimpinan sekolah terutama dalam pelaksanaan layanan bimbungan dan konseling.

3. Peranan pengawas BK

Peranan pengawas layangan bimbingan dan konseling antara lain untuk memantau, menilai, memperbaiki, meningkatkan dan mengembangkan kegiatan layanan bimbingan dan konseling. Selain mengawasi perkembangan dan pelaksanaan pendidikan di sekolah, pengawas juga melihat perkembangan pelaksanaan bimbingan dan konseling di sekolah tersebut

4. Peranan guru BK Konselor atau guru pembimbing
adalah pelaksana utama yang mengkoordinasi semua kegiatan yang terkait dalam pelaksana bimbingan dan koseling di sekolah. Konselor mengadakan kerja sama dengan guru-guru lain, sehingga guru-guru dapat meningkatkan mutu pelayanan dan pengetahuannya agar suksesnya program bimbingan dan konseling.

5. Peranan guru mata pelajaran

Prayitno (2008) memerinci peran, tugas dan tanggung jawab guru-guru mata pelajaran dalam bimbingan dan konseling adalah: 1) mengidentifikasi

Membantu

konselor memerlukan layanan bimbingan dan konseling, serta pengumpulan data tentang siswa-siswa tersebut; 2) Membantu memasyarakatkan pelayanan bimbingan dan konseling kepada siswa; 3) Mengalihtangankan siswa yang memerlukan pelayanan bimbingan dan konseling kepada konselor; 4) Menerima siswa alih tangan dari konselor, yaitu siswa yang menuntut konselor memerlukan pelayanan khusus, seperti pengajaran/latihan perbaikan, dan program pengayaan; 5) Membantu mengembangkan suasana kelas, hubungan guru siswa dan hubungan siswa-siswa yang menunjang pelaksanaan pelayanan pembimbingan dan konseling; 6) Memberikan kesempatan dan kemudahan kepada siswa yang memerlukan layanan/kegiatan bimbingan dan konseling untuk mengikuti/menjalani layanan/kegiatan yang dimaksudkan itu; 7) Berpartisipasi dalam kegiatan khusus penanganan masalah siswa, seperti konferensi kasus; dan 8) Membantu pengumpulan informasi yang diperlukan dalam rangka penilaian pelayanan bimbingan dan konseling serta upaya tindak lanjutnya.

\section{Peranan Wali Kelas}

Wali kelas sebagai mitra kerja konselor, juga memiliki tugas-tugas bimbingan dan konseling, yaitu: 1) Membantu guru bimbingan dan konseling melaksanakan layanan bimbingan dan konseling yang menjadi tanggung jawabnya; 2) Membantu memberikan kesempatan dan kemudahan bagi peserta didik, khususnya di kelas yang menjadi tanggung jawabnya, untuk mengikuti layanan bimbingan dan konseling; 3) Memberikan informasi tentang peserta didik di kelasnya untuk memperoleh layanan bimbingan dan konseling dari guru bimbingan dan konseling; 4) Menginformasikan kepada guru mata pelajaran tentang peserta dididk yang perlu diperhatikan khusus; 5) Mengalihtangankan siswa yang memerlukan layanan bimbingan dan konseling kepada guru pembimbing/konselor.

Peranan lingkungan keluarga dalam layanan bimbingan konseling

Lingkungan keluarga merupakan pendidikan pertama yang di lalui oleh siswa, tentu dalam pelaksanaannya lingkungan keluarga 
memiliki peranan penting dalam siswa melakukan pelanggaran yang sudah membentukkarakter siswa. Karakter kebaikan, ditetapkan sekolah; 2) Mengawasi pelaksanaan budi pekerti dan sopan tentulah diajarkan oleh konseling terkhusus pada siswa agar sekolah orang tuanya melalui lingkungan keluarga. tetap membantu dan mendukung cita-cita dan Sejalan dengan pendapat tersebut, Kartono kebutuhan masyarakat; dan 3) sebagai wadah (1982) menjelaskan peran penting orang tua konsultasi sekolah ketika siswa melakukan dalam mewujudkan kepribadian anak antara lain pelanggaran di lingkungan masyarakat.

bisa diwujudkan dengan beberapa hal sebagai berikut:

1. Kedua orang tua harus mencintai dan KESIMPULAN menyayangi anak-anaknya. Ketika anak-anak mendapatkan cinta dan kasih sayang cukup dari kedua orang tuanya, maka pada saat mereka berada di luar rumah dan menghadapi masalah-masalah baru mereka akan bisa menghadapi dan menyelesaikannya dengan baik. Sebaliknya jika kedua orang tua terlalu ikut campur dalam urusan mereka atau mereka memaksakan anak-anaknya untuk menaati mereka, maka perilaku kedua orang tua yang demikian ini akan menjadi penghalang bagi kesempurnaan kepribadian mereka.

2. Kedua orang tua harus menjaga ketenangan lingkungan rumah dan menyiapkan ketenangan jiwa anak-anak. Karena hal ini akan menyebabkan pertumbuhan potensi dan kreativitas akal anak-anak yang pada akhirnya keinginan dan kemauan mereka menjadi kuat dan hendaknya mereka diberi hak pilih.

3. Menciptakan kepercayaan terhadap anak. Menghargai dan memberikan kepercayaan terhadap anak-anak berarti memberikan penghargaan dan kelayakan terhadap mereka, karena hal ini akan menjadikan mereka maju dan berusaha serta berani dalam bersikap. Kepercayaan anak-anak terhadap dirinya sendiri akan menyebabkan mereka mudah untuk menerima kekurangan dan kesalahan yang ada pada diri mereka. Mereka percaya diri dan yakin dengan kemampuannya sendiri. Dengan membantu orang lain mereka merasa keberadaannya bermanfaat dan penting.

Peranan lingkungan masyarakat dalam layanan bimbingan konseling

Peranan masyarakat dalam layanan konseling di sekolah juga merupakan bagian yang tidak dapat dipiahkan, karena lingkungan masyarakan merupakan bagian dari lingkungan pendidikan. Dalam hal ini peranan masyarakat dalam kegiatan layan konseling diantaranya: 1) Memberikan kontrol dan informan sekolah ketika

Prayitno (2004) memerinci peran, tugas dan tanggung jawab kepala sekolah dalam bimbingan dan konseling yaitu: 1) Mengkoordinir segenap kegiatan yang diprogramkan dan berlangsung di sekolah, sehingga pelayanan pengajaran, latihan, dan bimbingan dan konseling merupakan suatu kesatuan yang terpadu, harmonis, dan dinamis. 2) Menyediakan prasarana, tenaga, dan berbagai kemudahan bagi terlaksananya pelayanan bimbingan dan konseling yang efektif dan efisien. 3) Melakukan pengawasan dan pembinaan terhadap perencanaan dan pelaksanaan program, penilaian dan upaya tidak lanjut pelayanan bimbingan dan konseling.

Mempertanggungjawabkan pelaksanaan pelayanan bimbingan dan konseling di sekolah. 5) Memfasilitasi guru pembimbing/konselor untuk dapat mengembangkan kemampuan profesionalnya, melalui berbagai kegiatan pengembangan profesi. Dan 6) Menyediakan fasilitas, kesempatan, dan dukungan dalam kegiatan kepengawasan yang dilakukan oleh Pengawas Sekolah Bidang BK.

Wakil kepala sekolah sebagi pembantu kepala sekolah, membantu kepala sekolah dalam melaksanakan tugas-tugas kepala sekolah dalam hal: 1) Mengkoordinasikan pelaksanaan layanan bimbingan dan konseling kepada semua personil sekolah; dan 2) Melaksanakan kebijakan pimpinan sekolah terutama dalam pelaksanaan layanan bimbungan dan konseling.

Peranan pengawas layangan bimbingan dan konseling antara lain untuk memantau, menilai, memperbaiki, meningkatkan dan mengembangkan kegiatan layanan bimbingan dan konseling. Selain mengawasi perkembangan dan pelaksanaan pendidikan di sekolah, pengawas juga melihat 
perkembangan pelaksanaan bimbingan dan konseling di sekolah tersebut

7. Peranan guru BK

Konselor atau guru pembimbing adalah pelaksana utama yang mengkoordinasi semua kegiatan yang terkait dalam pelaksana bimbingan dan koseling di sekolah. Konselor mengadakan kerja sama dengan guru-guru lain, sehingga guru-guru dapat meningkatkan mutu pelayanan dan pengetahuannya agar suksesnya program bimbingan dan konseling.

8. Peranan guru mata pelajaran

Prayitno (2008) memerinci peran, tugas dan tanggung jawab guru-guru mata pelajaran dalam bimbingan dan konseling adalah: 1) Membantu konselor mengidentifikasi siswa-siswa yang memerlukan layanan bimbingan dan konseling, serta pengumpulan data tentang siswa-siswa tersebut; 2) Membantu memasyarakatkan pelayanan bimbingan dan konseling kepada siswa; 3) Mengalihtangankan siswa yang memerlukan pelayanan bimbingan dan konseling kepada konselor; 4) Menerima siswa alih tangan dari konselor, yaitu siswa yang menuntut konselor memerlukan pelayanan khusus, seperti pengajaran/latihan perbaikan, dan program pengayaan; 5) Membantu mengembangkan suasana kelas, hubungan guru siswa dan hubungan siswa-siswa yang menunjang pelaksanaan pelayanan pembimbingan dan konseling; 6) Memberikan kesempatan dan kemudahan kepada siswa yang memerlukan layanan/kegiatan bimbingan dan konseling untuk mengikuti/menjalani layanan/kegiatan yang dimaksudkan itu; 7) Berpartisipasi dalam kegiatan khusus penanganan masalah siswa, seperti konferensi kasus; dan 8) Membantu pengumpulan informasi yang diperlukan dalam rangka penilaian pelayanan bimbingan dan konseling serta upaya tindak lanjutnya.

9. Peranan Wali Kelas

Wali kelas sebagai mitra kerja konselor, juga memiliki tugas-tugas bimbingan dan konseling, yaitu: 1) Membantu guru bimbingan dan konseling melaksanakan layanan bimbingan dan konseling yang menjadi tanggung jawabnya; 2) Membantu memberikan kesempatan dan kemudahan bagi peserta didik, khususnya di kelas yang menjadi tanggung jawabnya, untuk mengikuti layanan bimbingan dan konseling; 3) Memberikan informasi tentang peserta didik di kelasnya untuk memperoleh layanan bimbingan dan konseling dari guru bimbingan dan konseling; 4) Menginformasikan kepada guru mata pelajaran tentang peserta dididk yang perlu diperhatikan khusus; 5) Mengalihtangankan siswa yang memerlukan layanan bimbingan dan konseling kepada guru pembimbing/konselor.

\section{DAFTAR PUSTAKA}

Departemen Pendidikan Nasional. (2003). UU. No. 20. Th. 2003, Tentang Sistem Pendidikan Nasional. Bandung: Citra Umbara

Djumhur dan Moh. Surya. (2003). Bimbingan dan Penyuluhan di Sekolah. Bandung: Ilmu Citra Umbara.

Gunarsa, S.D. (2009). Psikologi untuk Keluarga. Jakarta: Gunung Mulia.

Hasgimianti. Nirwana, Herman. Daharnis. (2017). Perhatian Orang Tua dan Motivasi Belajar Siswa yang Berlatar Belakang Melayu dan Jawa. Insight: Jurnal Bimbingan dan Konseling, 6(2), 130-143.

Kartono, Kartini. 1982. Peranan Keluarga Memandu Anak, Sari Psikologi Terapan. Jakarta: Rajawali Press.

Miles, M.B \& Huberman A.M. (1992). Analisis Data Kualitatif. Terjemahan oleh. Tjetjep Rohendi Rohidi. Jakarta: Penerbit Universitas Indonesia.

Mizan, I.K. 2012. Pengaruh Lingkungan Keluarga Terhadap Prestasi Belajar Siswa Kelas X Program Keahlian Teknik Elektronika SMK N 1 Magelang Tahun Pelajaran 2011/2012. Artikel Ilmiah (online)

http://eprints.uny.ac.id/9607/1/Jurnal.pdf. diakses tanggal 07 April 2018.

Moleong Lexy J. (2006). Metodologi Penelitian Kualitatif. Bandung: Remaja Rosdakarya.

Monalisa, Riana Tamara. (2016). Peranan Lingkungan Sosial terhadap Pembentukan Sikap Peduli Lingkungan Peserta Didik di SMA Negeri Kabupaten Cianjur. Gea, Jurnal Pendidikan Geografi, Volume 16, Nomor 1, 44-55. 
Prayitno. 2004. Layanan Bimbingan Kelompok dan Konseling Kelompok. Padang: Universitas Negeri Padang.

Prayitno. Erman Amu. 2008. Dasar-dasar Bimbingan dan Konseling. Jakarta: Rhineka Cipta.

Simanullang, Halasan. Wahjoedi. Sapto, Ari. (2017). Peran Lingkungan Keluarga dalam Meningkatkan Prestasi Belajar Siswa. Artikel ilmiah Program Studi Pendidikan Dasar, Pascasarjana Universitas Negeri Malang, $\quad 1-9 \quad$ (online) http://pasca.um.ac.id/conferences/index.ph $\mathrm{p} / \mathrm{gtk} /$ article/viewFile/262/246, diakses 07 April 2018.

Sugiyono. (2017). Metode Penelitian Kuantitatif, Kualitatif, dan R\&D. Bandung: Alfabeta

Yarliani, Ikta. (2013). Peran Guru Bimbingan dan Konseling Membantu Mengatasi Masalah Hubungan Sosial Siswa di Madrasah Tsanawiyah Negeri Banjarmasin Selatan Kota Banjarmasin. Jurnal: Guidance and Counseling, Volume 1 Issue 1, 46-54. (online)

http://download.portalgaruda.org/article.ph p?article $=334145 \&$ val $=7813 \&$ title $=$ PERA N\%20GURU\%20BIMBINGAN\%20DAN \%20KONSELING\%20MEMBANTU\%20 MENGATASI\%20MASALAH\%20HUBU NGAN\%20SOSIAL\%20SISWA\%20DI\%2 OMADRASAH\%20TSANAWIYAH\%20N EGERI\%20BANJARMASIN\%20SELAT AN\%20KOTA\%20BANJARMASIN.

Diakses 8 April 2018. 